\section{Intersections}

Canadian Journal of Music

Revue canadienne de musique
Intersections CANADIAN JOURAL OF MUSIO

\title{
The Jack Pine: Preserving the Northern Ontario Landscape through Painting, Music, and Short Film
}

\section{Roxane Prevost}

Volume 36, numéro 2, 2016

URI : https://id.erudit.org/iderudit/1051596ar

DOI : https://doi.org/10.7202/1051596ar

Aller au sommaire du numéro

Éditeur(s)

Canadian University Music Society / Société de musique des universités canadiennes

ISSN

1911-0146 (imprimé)

1918-512X (numérique)

Découvrir la revue

Citer cet article

Prevost, R. (2016). The Jack Pine: Preserving the Northern Ontario Landscape through Painting, Music, and Short Film. Intersections, 36(2), 35-45.

https://doi.org/10.7202/1051596ar
Résumé de l'article

Dans ses notes de programmes, la compositrice canadienne Jocelyn Morlock explique qu'elle a été inspirée par le tableau de 1916-17 de Tom Thomson, représentant un pin gris s'agrippant à un affleurement rocheux au bord de l'eau, pour la composition de sa pièce solo pour piano intitulée The Jack Pine (2010). Un peu plus tard, Julian Beecroft a réalisé un court métrage au sujet du Parc Algonquin sur la musique de Morlock. Cet article examine quelques correspondances entre les transitions de couleurs et la façon dont la musique illustre avec succès certaines scènes du court métrage.
Copyright ( C Canadian University Music Society / Société de musique des universités canadiennes, 2018
Ce document est protégé par la loi sur le droit d'auteur. L'utilisation des services d’Érudit (y compris la reproduction) est assujettie à sa politique d'utilisation que vous pouvez consulter en ligne.

https://apropos.erudit.org/fr/usagers/politique-dutilisation/ 


\title{
THE JACK PINE: PRESERVING THE NORTHERN ONTARIO LANDSCAPE THROUGH PAINTING, MUSIC, AND SHORT FILM
}

\author{
Roxane Prevost
}

Canadian composer Jocelyn Morlock (b. 1969) has increasingly gained international acclaim for her lyricism and exquisite use of harmonic colours. ${ }^{1} \mathrm{Her}$ work The Jack Pine for solo piano (2010) was inspired by Tom Thomson's 191617 painting, which depicts a Jack pine on the edge of water with mountains and the sky in the background. In her program note, Morlock explains that she was influenced by the "delicate and majestic" aspects of the northern Ontario tree in the painting (2010). Subtle changes in harmonic and registral colours allow the composer to project the "stillness of the water and sky" and the "endless gradations of colour within them" (2010). The gradual shift in colours in the painting is reflected by the gradual shift in the changing chords in the music and the use of the full range of the piano to gently highlight some of these changes. Although the music captures the essence of the painting, Julian Beecroft also posted a short film of the Algonquin Park, accompanied by Morlock's work, as part of his trans-Canada blog (2011). The short film was shot and edited by his uncle Stuart Beecroft, a video producer familiar with the Algonquin Park. This article examines intersections between the transition of colours in the painting and the harmonic colours of the music through voice-leading analysis, and some of the ways in which the music depicts scenes of the film. The three works interact by drawing attention to the subtleties and stunning landscape of the northern Ontario wilderness.

\section{Tom Thomson and The Jack Pine}

Tom Thomson (1877-1917) is an iconic artist known for his depictions of the northern Ontario landscape. Although he died before the Group of SevenFranklin Carmichael, Lawren Harris, A.Y. Jackson, Frank Johnston, Arthur Lismer, J.E.H. MacDonald, and Frederick Varley—was formed, he profoundly influenced these artists (Newlands 1995, 6). His painting The Jack Pine (1916-17) remains one of his last and most popular works. It depicts a Jack pine growing

1 For more information on Morlock and her works, consult her webpage and the Canadian Music Centre's showcase on the composer. 
in a rock by the edge of water with mountains in the background; two other Jack pines appear closer to the water. Thomson subtly blends colours into one another, making the change gradual. Silcox describes the painter's use of colours for the sky and background as "subtle modulations from the yellow-green sunset clouds at the horizon through to the bluish arc" $(2015,50)$. These changes in the colours of the background are created by strong horizontal strokes for the sky, water, and foliage on the rocks that give the work "an almost overwhelming feeling of solemn stability" (Reid 1975, 30). This sets the atmosphere for the scene and focuses our attention to the tree on the shoreline. Thomson's blending of colours captures the movement of a vivid scene, rather than reproducing a snapshot of a moment in time, allowing us to imagine experiencing the beautiful landscape of northern Ontario.

\title{
Jocelyn Morlock and The Jack Pine
}

Inspired by Thomson's painting, Morlock wrote a piano piece with the same title. The Jack Pine (2010) was commissioned for the Gallery Project, a partnership of Music and Beyond, CBC Radio Two, and the National Gallery of Canada. It was premiered in 2011 by Peter Longsworth with a recording by the CBC; it has also been recorded commercially by Elaine Keillor (2013). In her program note accompanying the work, Morlock explains,

\begin{abstract}
Several aspects of Tom Thomson's The Jack Pine were seminal in creating this piece. I was intrigued by the way that the tree is both delicate and majestic, almost heroic in the way that it clings to life on the side of the cliff. (Jack Pines will grow where there has been a forest fire or other destruction of previous ground cover.) The absolute stillness of the water and sky, and the endless gradations of colours within them, influenced both the stillness of the outer sections of the piece, and my experiment with variations of colour within large chords. The centre of the piece is created from a spectrum of chords, each with its own slight change of colour/timbre. ${ }^{2}$
\end{abstract}

As highlighted by the composer, this piano work unfolds as a ternary form with the last section reprising some of the material of the first section. The reprise is not literal, but rather a truncated version with variations of the main motives. Morlock uses registral and harmonic colours to represent the idea of stillness in the first and last sections of the work, while the contrasting middle section focuses primarily on chords changing colours.

The first section (mm. 1-32) opens with whole notes, a tempo of the quarter note equal to 80 , and the marking "sempre con rubato, expressive," as well as "sempre molto Ped." Throughout the first section, Morlock repeats and varies three main motives. The first, labelled motive $a$, consists of a whole-note or halfnote motive with two voices, one moving from $C$ to $B$ and the other $F$ to $G$ (see example 1). (The motives will be discussed in more detail below.) The second motive, motive $b$, casts the notes E-flat and $\mathrm{C}$ in different ways, including an

2 Morlock's score is available online from the Canadian Music Centre at https://www. musiccentre.ca/node/36074. 
oscillation between the two pitches and grace note Cs and/or E-flats embellishing a whole-note or half-note E-flat or $\mathrm{C}$. This motive differs from motive $a$ by its more rapid durations and being limited to two pitch classes. The last motive, motive $c$, unfolds as the arpeggiated figure in $\mathrm{mm}$. 14-15. Its pitch-class content includes the ones from motives $a$ and $b$, but these do not move to the same pitches as in the previous motives. Morlock also adds a D and an A-flat. Motive $c$ differs from the previous two motives primarily through the different pitch classes, but it is also articulated as descending arpeggiations. The three motives occur primarily in the upper register, although Morlock includes a descent into the lower register at m. 28.

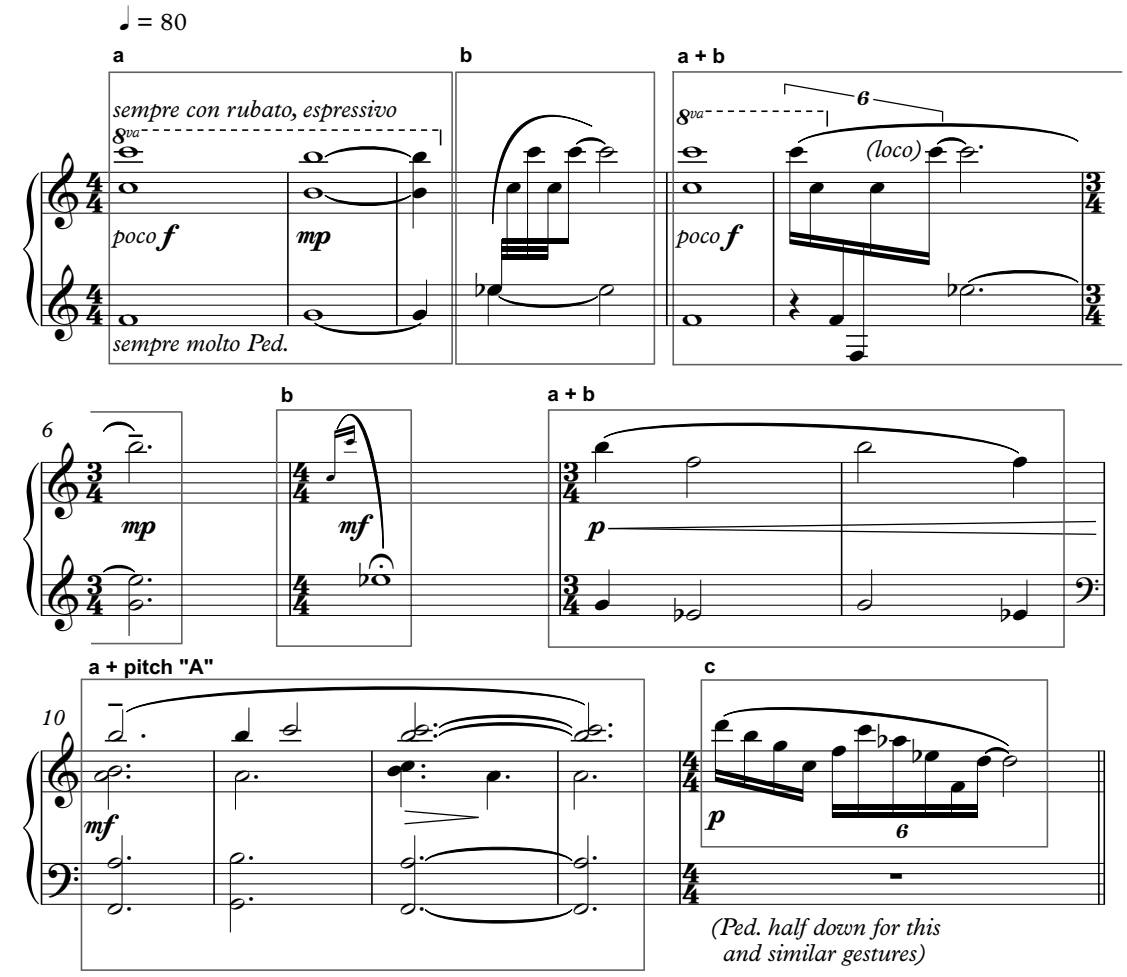

Example 1. Morlock's The Jack Pine, mm. 1-14, three primary motives. (C) 2010 Jocelyn Morlock, by permission

As previously mentioned, Morlock limits the pitch-class material of the individual motives in mm. 1-14. This provides a means to evoke different elements of the painting through variations of the motives. The opening gesture (motive a) projects stillness with the interval of a perfect fifth and superimposed perfect octave in the higher range of the piano, which moves to a major third with a perfect octave above it. This gesture or the movement of lines (B to $\mathrm{C}$ [or $\mathrm{C}$ to $\mathrm{B}$ ] and $\mathrm{F}$ to $\mathrm{G}$ ) becomes a building block for the work. Although the opening sonority consists of the intervals of the perfect fifth and perfect 
octave, the contrary motion in the upper and lower lines, combined with the repetition of the motive, give a sense of tension to the major third ( $G$ and $B$ ) that follows, in part because the note $\mathrm{C}$ returns with motive $b$. The semitone motion is prominent, since it occurs as the highest voice, and the tension of the semitone $\mathrm{B}$ to $\mathrm{C}$ becomes greater in $\mathrm{mm} .8-12$ as the two notes appear together in $\mathrm{m}$. 12. Although Morlock includes no key signature, and the pitch-class $\mathrm{C}$ is highlighted through register and repetition, the opening section only hints at a C-minor tonality with motives $a$ and $b$. The opening section projects stillness, rather than moving towards a cadence. The whole-note durations also contribute to the effect of stillness, as does the performance indication included with the program note: "Feel free to use lots of pedal throughout to create a sustained and even slightly blurry sound" (Morlock 2010). At m. 10, Morlock expands motive $a$ by adding the pitch-class $\mathrm{A}$. The second motive-motive $b-$ (fast durations with the pitch-classes E-flat and C) in mm. 3 and 7 combines with motive $a$ with the $\mathrm{E}$ flat sounding at the same time as the $\mathrm{C}$ and then a $\mathrm{G}$ and $\mathrm{B}$ in $\mathrm{m} .5$. The $\mathrm{E}$ flat returns to sound against the $\mathrm{F}_{5}$ in $\mathrm{mm} .8$ and 9. The last of the three motives-motive $c$ in $\mathrm{mm} .14-15$-includes the indication "Ped. half down for this and similar gesture." Along with the quick durations (sixteenth notes and sixteenth-note sextuplets), this changes the colour of the arpeggiated motive. This motive, however, plays a less significant role in the first section, for it occurs only in mm. 14-15; it becomes more prominent in the last section of the work. Since the three motives repeat without a specific order and always slightly varied, we may perceive a sense of stillness or suspended movement. The slow durations of the opening gesture combined with the sparse texture, the sustained notes, and the consonant intervals also contribute to this perception of stillness. One could associate the pitches in the high register and the open perfect fifths as the open water with the reflection of the sun on it. The arpeggiated sixteenth notes in $\mathrm{mm} .14-15$ (motive $c$ ) could evoke a gentle breeze on the water or going through the branches of the tree. The stillness of the opening section represents the calmness and slow movement projected by the painting. Its focus is on the overall mood of the painting.

Morlock marks the beginning of the contrasting section (mm. 33-49) with a key change (five flats added to the key signature), ${ }^{3}$ a change in tempo (quarter note equals eighty beats per minute to quarter note equals sixty-six beats per minute), a change in time signature to $4 / 4$, a move back into the higher register, and the indication "sempre molto Ped, very blurred." We may perceive this middle section as less reflective and peaceful than section $\mathrm{A}$, since the composer does not include the repetition of specific motives; instead, she preserves the upper parts of the chords while dramatically changing the left hand of the piano. The section opens with a dyad, which gradually adds notes to eventually turn into dense chords in a crescendo to the climax with triplet-quarter notes at m. 45 .

3 Morlock included the change in key signatures (to D-flat) for aesthetic ends, rather than a means to highlight a tonal centre: "I choose key areas by tone colour (as I perceive it-for instance, this section wouldn't make sense to me in a sharp key, because I generally hear it as warmer, not a bright timbre), and I try to make the accidentals as uncomplicated as I can" (e-mail message to author, 23 January 2018). 
Although common tones prevail, there is always movement, since the composer preserves certain pitches (in the same register) from one chord to the next but rarely repeats chords exactly as they are first stated. The subtle differences allow for movement but with something always familiar. Measures 41-44 serve as a good example of this compositional strategy (see example 2). As the voice-leading analysis shows, many pitches remain the same, especially in the right hand of the piano (see figure 1). For example, the C6 is repeated in different chords in the upper voice; it moves to a C-flat6 only once before returning to C6. The movement in the left hand sinks into the lowest register of the piano. The dense chords capture the grounded tree swaying in the wind in isolation from other trees, as well as its struggle to survive as it "clings to the rock." The common tones also convey the subtle changes in colours in the painting. Although Morlock gradually alters the chords, she preserves an element of the original chord as the harmonic colours blend into each other through common tones.

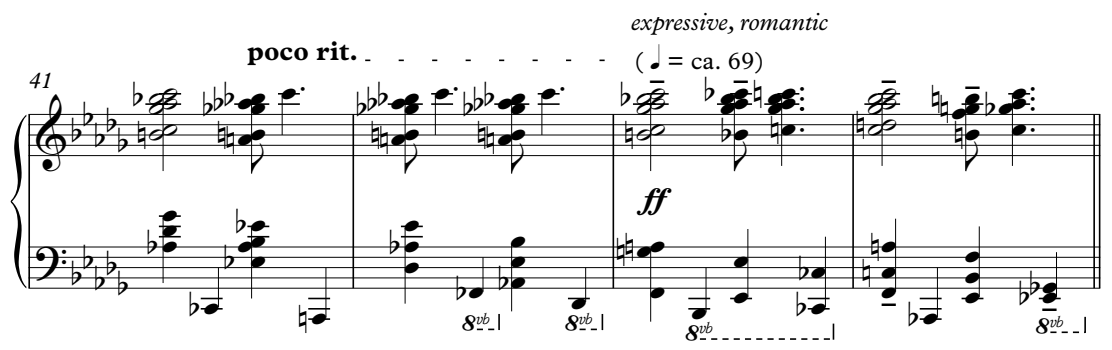

Example 2. Morlock's The Jack Pine, mm. 41-4. (C) 2010 Jocelyn Morlock, by permission

Morlock brings back the original key signature for the return of the motives from the opening section, but this time the pitch-class content of motives $a$ and $b$ is combined with the pitch-class A to create the static chords. Although motives $a$ and $b$ are amalgamated and no longer function as separate entities, motive $c$ gains more prominence and is set apart from the other material through durations and triadic leaps. The prominence of motive $c$ in this closing section could represent the strength and reserve of the tree as it withstands the harsh environment.

\section{Julian ANd STEWART BeEcroft ANd THE LAND of THE JACK PINE}

For his trans-Canada blog "Coast to Coast with Tom Thomson and the Group of Seven: Algonquin Park," Julian Beecroft, while travelling the park with his uncle Stuart Beecroft, set out to explore some of the landscapes sketched or painted by Thomson and the Group of Seven. ${ }^{4}$ Stuart Beecroft, who shot and edited the short film that was set to Longworth's performance of Morlock's music, is familiar with the landscape of Algonquin Park, having produced

4 For the blog, see Beecroft (2011a), and for the film see Beecroft (2011b). 


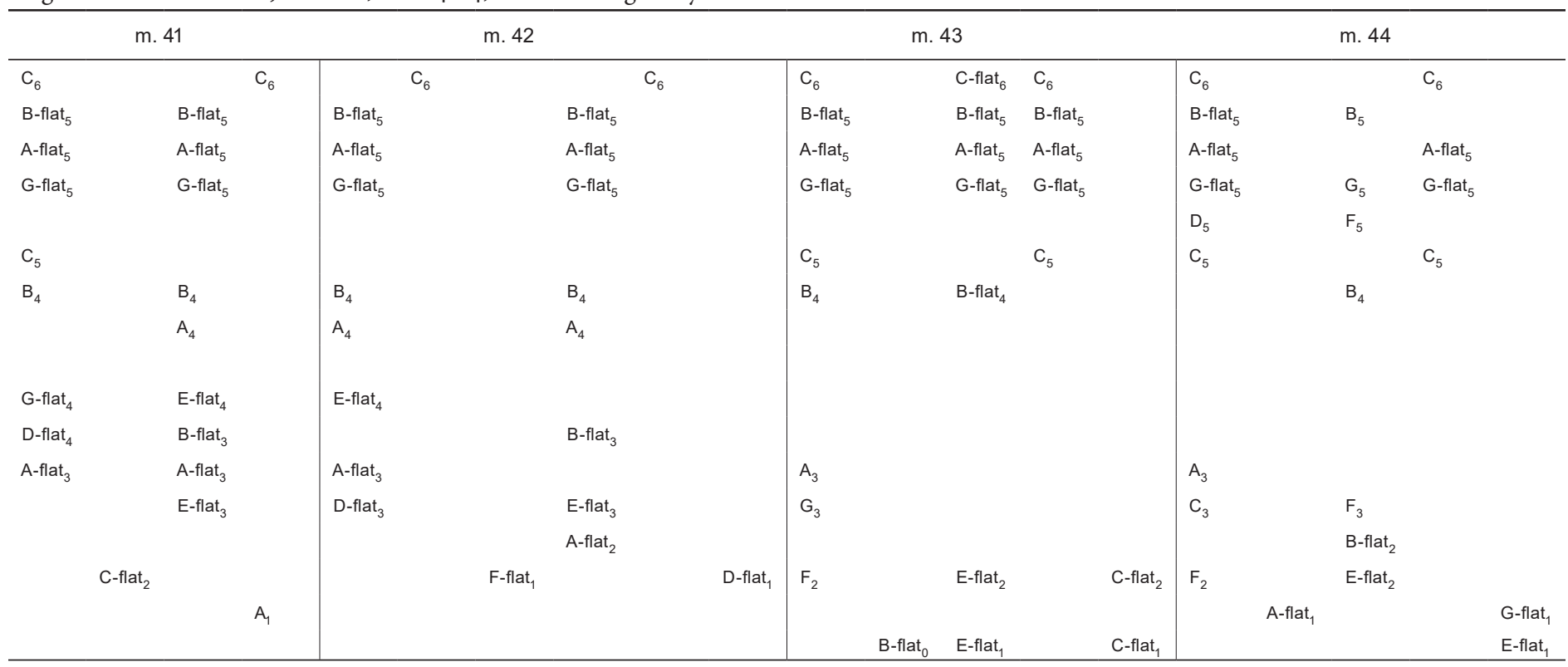


displays for the park's visitor centre. In the film, Beecroft follows Morlock's overall ternary form through a number of short scenes. In the A section, he includes the sun on the water, trees, rocks, and gently flowing water in thirteen scenes (see figure 2). The change in scenes often aligns with the beginning of motivic statements or a repetition within the statement of the motive. The opening reproduces stillness with the water scenes, which increasingly become more agitated; however, the movement remains relatively small. This coincides primarily with statements of motives $a$ and $b$, more specifically the whole-note two-voice movement of motive $a$ and the oscillating E-flat and C of motive $b$. The combination of the two motives accompanies scene 2 and part of scene 3 , which turns to the visual of trees, while the last part of scene 3 with trees turns to motive $a$ with the added A. Beecroft then includes scenes with rocks, water, and trees for the remainder of the first section. These images align with statements of the three motives. For the last four scenes, with statements of motive $a$ with motive $b$ added, Beecroft includes an aerial shot, which gives the impression of being removed. The first section ends with an E-flat (from motive $b$ ) and $\mathrm{F}$ (from motive a) with the aerial shot, followed by pine trees growing on a big rock in the middle of the water; the camera moves towards the tree in this scene, which will continue into the contrasting section B. Although the visuals document life, there is stillness and calmness in these opening scenes, mirroring the mood projected by the music and the painting.

Figure 2: Beecroft's film (o:0o-2:02) and Morlock's section A (mm. 1-35)

\begin{tabular}{|c|c|c|c|}
\hline Description & Film scene & Measure number & Motive \\
\hline \multirow[t]{3}{*}{ Sun and light on water } & 1 & m. 1 & motive a; motive $b$ \\
\hline & 2 & m. 4 & motives $a$ and $b$ combined \\
\hline & 3 & m. 7 & $\begin{array}{l}\text { motive } b \text {; motives } a \text { and } b \\
\text { combined }\end{array}$ \\
\hline Trees & 4 & m. 9 & $\begin{array}{l}\text { motives } a \text { and } b \text { combined; mo- } \\
\text { tive } a+\operatorname{pitch} A\end{array}$ \\
\hline \multirow[t]{6}{*}{ Rocks, water, and trees (close) } & 5 & m. 11 & $\begin{array}{l}\text { motive } a+\text { pitch } \mathrm{A} \\
\text { motive } c\end{array}$ \\
\hline & 6 & m. 14.3 & motive $c$; motive a + pitch A \\
\hline & 7 & m. 19 & $\begin{array}{l}\text { motive } c \text {; motive a + pitch } \mathrm{A} \text {; } \\
\text { motive } b\end{array}$ \\
\hline & 8 & m. 20 & motive $a+$ pitch $\mathrm{A} ;$ motive $b$ \\
\hline & 9 & m. 22 & $\begin{array}{l}\text { motive a + pitch A; motive } b \\
\text { added }\end{array}$ \\
\hline & 10 & m. 24 & motive a + pitch A \\
\hline \multirow[t]{2}{*}{ (Aerial) } & 11 & m. 26 & $\begin{array}{l}\text { motive } a+\text { pitch } \mathrm{A} ; \text { motive } b \\
\text { added }\end{array}$ \\
\hline & 12 & m. 29.3 & $\begin{array}{l}\text { motive } a+\text { pitch A; motive } b \\
\text { added }\end{array}$ \\
\hline $\begin{array}{l}\text { Pine trees growing on a big } \\
\text { rock in the middle of water }\end{array}$ & 13 & m. 32.2 & $\begin{array}{l}\text { E-flat (from motive } b \text { ) and } \mathrm{F} \text { (from } \\
\text { motive } a \text { ) }\end{array}$ \\
\hline
\end{tabular}


Beecroft overlaps the end of section A with the beginning of section B by prolonging scene 13 with pine trees growing on a big rock in the middle of the water. The remainder of section B includes more footage of rocks, water, and pine trees, highlighting the harshness of the environment. This section seems far more turbulent, especially with the scenes of the pine tree, not only with the actual footage, but also through the number of different scenes (twentyone). The scenes are largely accompanied by vertical sonorities, rather than the three motives. Measures 37 to 46 are particularly striking, with most scenes changing at the rate of the half note. These measures consist primarily of chords sharing common tones in the upper voices with descending motion in the left hand, as discussed with figure 1. The quarter-note triplets in the right hand of the piano in m. 45 (scenes 27 and 28) mark the climax of the movement through register and the faster moving lines. This is followed by chords until the return of section A. The footage of the trees in these scenes conveys the harshness of the terrain and environment with fallen pine trees, dry trees, and some dead trees (see figure 3). Beecroft moves from these dramatic visuals back to the water, rocks, and sunset to restore the tranquillity of the painting and of section A. The green trees along the shoreline at $\mathrm{m} .47$ (scene 33) remind us of the pine tree's survival in this environment. The images in these twenty-one scenes align well with the music, since the contrasting section of Morlock's work is more dramatic with the chord changes and a gradual crescendo to the quarter-note triplets at m. 45 .

Figure 3: Beecroft's film (2:03-3:12) and Morlock's section B (mm. 36-49)

\begin{tabular}{|c|c|c|c|}
\hline Description & Film scene & $\begin{array}{l}\text { Measure } \\
\text { Number }\end{array}$ & \\
\hline $\begin{array}{l}\text { Pine trees growing on } \\
\text { a big rock in the middle } \\
\text { of water }\end{array}$ & 13 & m. 32.2 & $\begin{array}{l}\text { E-flat (from motive } b \text { ) and } \mathrm{F} \text { (from motive a); } \\
\text { descending half-note chords (accumulation of } \\
\text { pitches) }\end{array}$ \\
\hline Rocks with trees & 14 & m. 36.3 & Half-note chord \\
\hline $\begin{array}{l}\text { Pine trees, some fallen } \\
\text { down, }\end{array}$ & 15 & m. 37.3 & $\begin{array}{l}\text { Half-note chords; quarter-note chords in the left } \\
\text { hand }\end{array}$ \\
\hline some dry, some & 16 & m. 38.1 & Half-note chord \\
\hline \multirow[t]{5}{*}{ dead } & 17 & m. 38.3 & Half-note chords; quarter-notes in the left hand \\
\hline & 18 & m. 39.3 & $\begin{array}{l}\text { Chords (eighth note + dotted-quarter notes in } \\
\text { right hand; quarter notes in left hand) }\end{array}$ \\
\hline & 19 & m. 40 & $\begin{array}{l}\text { Half-note chords in the right hand with quar- } \\
\text { ter-note chords in the left hand; eighth-note } \\
\text { chord and dotted-quarter note in right hand; } \\
\text { quarter notes in left hand }\end{array}$ \\
\hline & 20 & m. 41.1 & $\begin{array}{l}\text { Half-note chord in right hand with quarter-notes } \\
\text { in the left hand }\end{array}$ \\
\hline & 21 & m. 41.3 & $\begin{array}{l}\text { Eighth-note chord with dotted-quarter notes in } \\
\text { the right hand; quarter notes in left hand }\end{array}$ \\
\hline
\end{tabular}


Figure 3 cont'd

\begin{tabular}{|c|c|c|c|}
\hline Description & Film scene & $\begin{array}{l}\text { Measure } \\
\text { Number }\end{array}$ & \\
\hline & 22 & m. 42.1 & $\begin{array}{l}\text { Eighth note chord with dotted-quarter notes in } \\
\text { the right hand; quarter notes in left hand }\end{array}$ \\
\hline & 23 & m. 42.3 & $\begin{array}{l}\text { Eighth-note chord with dotted-quarter note in the } \\
\text { right hand; quarter notes in left hand }\end{array}$ \\
\hline & 24 & m. 43.1 & $\begin{array}{l}\text { Half-note chord in the right hand; quarter notes } \\
\text { in the left hand; end of gradual crescendo }\end{array}$ \\
\hline \multirow[t]{3}{*}{$\begin{array}{l}\text { Water, night and water, } \\
\text { sunset }\end{array}$} & 25 & m. 43.3 & $\begin{array}{l}\text { Eighth-note chord with dotted-quarter notes in } \\
\text { the right hand; quarter notes in left hand }\end{array}$ \\
\hline & 26 & m. 44 & $\begin{array}{l}\text { Half-note chords in the right hand with quarter } \\
\text { notes in the left hand; eighth-note chord with } \\
\text { dotted-quarter notes in the right hand; quarter } \\
\text { notes in the left hand }\end{array}$ \\
\hline & 27 & m. 45.1 & $\begin{array}{l}\text { Descending triplet-quarter note dyads and } \\
\text { trichords in the left hand and quarter-note dyads } \\
\text { in the right hand }\end{array}$ \\
\hline \multirow[t]{6}{*}{$\begin{array}{l}\text { Water flowing down } \\
\text { rocks, trees and rocks, } \\
\text { shoreline }\end{array}$} & 28 & m.45.3 & $\begin{array}{l}\text { Descending triplet-quarter note tetrachords in } \\
\text { the left hand and quarter-note dyads in the right } \\
\text { hand }\end{array}$ \\
\hline & 29 & m. 46.1 & $\begin{array}{l}\text { Half-note tetrachord in the left hand with quarter } \\
\text { notes in the right hand; start of decrescendo }\end{array}$ \\
\hline & 30 & m. 46.3 & $\begin{array}{l}\text { Half-note tetrachord in the left hand with quarter } \\
\text { notes in the right hand }\end{array}$ \\
\hline & 31 & m. 47.3 & $\begin{array}{l}\text { Half-note tetrachord in the right hand and quar- } \\
\text { ter-note dyads in the left hand }\end{array}$ \\
\hline & 32 & m. 48.3 & $\begin{array}{l}\text { Half-note tetrachord in the right hand and quar- } \\
\text { ter-note dyads in the left hand }\end{array}$ \\
\hline & 33 & m. 49 & $\begin{array}{l}\text { Pentachord in the right hand and quarter notes } \\
\text { in the left hand }\end{array}$ \\
\hline
\end{tabular}

With the return of section A, Beecroft restores the stillness of the opening with the pine trees on the shoreline growing from rocks (m. 50), which eventually lead to landscape similar to the painting (see figure 4), through ten scenes, some of which include still photos. At m. 53.2 (scene 35), as motive $c$ with its arpeggiated figure is set to return, a canoe moving away through an inlet features the first and only human in the film. This most likely refers to Thomson's death, which was reported as a drowning while he was canoeing. Motive $c$ recurs in m. 57 accompanied by a cluster in the left hand (F-G-A), before turning to the pitch-class content of motives $a$ and $b$, articulated as two simultaneous melodic lines. The repetition of motive $c$ aligns with the visual of a dam with the shoreline and trees at m. 57 (scene 36), highlighting how humans have altered parts of Algonquin Park, but many areas remain pristine. Motive $c$ is articulated more concisely through fewer repetitions of the pitches, but the pitch classes and contours associated with this motive are preserved. Beecroft aligns the visuals of the sky and mountains of scene 37 and Morlock's amalgamated motives $a$ and $b$ with the pitch-class A (m. 60), which persist until motive $c$ returns halfway through scene 37 . The last seven scenes (scenes 37-43) gradually bring us back to the essence of the painting through images of the sky, mountains, 
rocks, water, trees, and sunset. The music supports these images by the amalgamation of motives $a$ and $b$ with the pitch $\mathrm{A}$, except for one interjection from motive $c$ in $\mathrm{m}$. 66. At $\mathrm{m} .67$, a lone pine tree stands by the water (scene 39); Beecroft pans left to a larger pine tree growing from a rock with water and mountains in the background. The sunsets in mm. 71-2 (scenes 41-3) resemble the one in Thomson's painting. The film ends with a full moon with a pine tree on the right, supported by the pitch-classes $\mathrm{G}-\mathrm{F}-\mathrm{A}$ from motive $a$. This brings the film to a close, as if documenting one day in the wilderness.

Thomson's painting has captured the imagination of many admirers. The Jack Pine brings to life the essence of a pine tree clinging to a rock with a peaceful landscape in the background. Morlock's work aurally depicts the essence of the painting through motivic manipulation and chordal voice leading. The horizontal strokes of the painting become individual motives in the piano work, while the subtle changes of colours in the painting are reproduced through chords with common tones in the contrasting section $\mathrm{B}$ of the piano piece. The film complements the painting and the musical work by producing current visuals of the Jack pine in its natural environment. Beecroft presents the tree's struggle to survive, but also the natural beauty of the park. The three works comment on each other by blending the harsh terrain of northern Ontario's wilderness with the wonderfully serene landscape that originally inspired Thomson.

Figure 4. Beecroft film (3:13-5:33) and Morlock's section A' (10 scenes, mm. 50-73)

\begin{tabular}{|c|c|c|c|}
\hline Description & Film scene & $\begin{array}{l}\text { Measure } \\
\text { number }\end{array}$ & Motive \\
\hline $\begin{array}{l}\text { Pine trees on shore } \\
\text { in rock }\end{array}$ & 34 & m. 50 & motive $a+$ pitch $\mathrm{A}+$ motive $b$ \\
\hline $\begin{array}{l}\text { Canoe in inlet (shore- } \\
\text { line with trees) }\end{array}$ & 35 & m. 53.3 & motive $a+$ pitch $\mathrm{A}+$ motive $b ;$ motive $c$ \\
\hline $\begin{array}{l}\text { Dam with shoreline and } \\
\text { trees }\end{array}$ & 36 & m. 57 & motive $c ;$ motive $a+$ pitch $\mathrm{A}+$ motive $b$ \\
\hline $\begin{array}{l}\text { Elements of painting } \\
\text { (sky, mountains) }\end{array}$ & 37 & m. 60 & motive $a+$ pitch $\mathrm{A}+$ motive $b ;$ motive $c$ \\
\hline Rocks and water & 38 & m. 63 & motive $a+$ pitch $\mathrm{A}+$ motive $b ;$ motive $c$ \\
\hline Element of & 39 & m. 68 & motive $a+$ pitch $\mathrm{A}+$ motive $b$ \\
\hline $\begin{array}{l}\text { painting (lone pine } \\
\text { trees by }\end{array}$ & 40 & m. 71.2 & motive $a+$ pitch $\mathrm{A}+$ motive $b$ \\
\hline water, mountains, & 41 & m. 71.4 & motive $a+$ pitch $\mathrm{A}+$ motive $b$ \\
\hline $\begin{array}{l}\text { sunset on water, sunset } \\
\text { with trees) }\end{array}$ & 42 & m. 72 & motive a \\
\hline $\begin{array}{l}\text { Moon with pine tree } \\
\text { on right }\end{array}$ & 43 & m. 72.4 & motive a \\
\hline
\end{tabular}

\section{REFERENCES}

Beecroft, Julian. 2011a. "Coast to Coast with Tom Thomson and the Group of Seven: Algonquin Park." http://dulwichonview.org.uk/2011/10/14/ 
coast-to-coast-with-tom-thomson-and-the-group-of-seven-algonquinpark/.

2011b. "Land of the Jack Pine." https://www.youtube.com/watch? time $\_$continue $=5 \& \mathrm{v}=\mathrm{hhb}$ AvPAePdw.

Keillor, Elaine. 2013. Sounds of North: Two Centuries of Canadian Piano Music. Gala Bo1NBUUHP2, compact disc.

Morlock, Jocelyn. 2010. "The Jack Pine." Canadian Music Centre. https:// musiccentre.ca/node/37616/sheet music.

. 2018. Homepage. www.jocelynmorlock.com/.

Newlands, Anne. 1995. The Group of Seven and Tom Thomson: An Introduction. Willowdale, ON: Firefly Books.

Reid, Dennis. 1975. The Jack Pine / Le pin. Ottawa: National Gallery of Canada. Silcox, David P. 2015. Tom Thomson, Life and Works. Toronto: Art Canada Institute. https://www.aci-iac.ca/art-books/tom-thomson.

\begin{abstract}
In her program note, Canadian composer Jocelyn Morlock explains that she was inspired by Tom Thomson's 1916-17 painting, which depicts a Jack pine clinging to a rock on the edge of water, for her solo piano piece The Jack Pine (2010). Julian Beecroft later posted a short film of the Algonquin Park, accompanied by Morlock's work. This article examines some of the intersections between the transition of colours in the painting and the harmonic colours of the music through voice-leading analysis, and some of the ways in which the music successfully depicts the different scenes of the short film.
\end{abstract}

\title{
RÉSUMÉ
}

Dans ses notes de programmes, la compositrice canadienne Jocelyn Morlock explique qu'elle a été inspirée par le tableau de 1916-17 de Tom Thomson, représentant un pin gris s'agrippant à un affleurement rocheux au bord de l'eau, pour la composition de sa pièce solo pour piano intitulée The Jack Pine (2010). Un peu plus tard, Julian Beecroft a réalisé un court métrage au sujet du Parc Algonquin sur la musique de Morlock. Cet article examine quelques correspondances entre les transitions de couleurs et la façon dont la musique illustre avec succès certaines scènes du court métrage.

\section{BIOGRAPHY}

Roxane Prevost is associate professor at the University of Ottawa, where she teaches undergraduate and graduate music theory and analysis. Her research interests include post-tonal music, rhythmic theories, and the music of Canadian composers. She has published articles in Intersections, Ex tempore: The Journal of Music Theory Pedagogy, Musurgia, and Australasian Canadian Studies and has presented at conferences in Canada, the United States, and Europe. 